\title{
LA VISIÓN INTEGRADORA DE ÁNGEL CRESPO'
}

\author{
Armando López CASTRO \\ Universidad de León
}

En su texto en prosa "Presencia de Ángel Crespo", incluido en Textos para Ángel Crespo (1986), después de subrayar el conocimiento del escritor manchego por sus obras, la sostenida actualidad de su escritura y el valor musical de sus versos, Jaime Gil de Biedma finaliza así su breve contribución: “Y al hablar de ellos pienso también en sus trabajos de crítica literaria y en su importantísima obra de traductor, de consumado introductor de las modernas literaturas de lengua portuguesa entre nosotros, tan distraídos siempre entre cosas de menos importancia". Poeta, crítico y traductor, tres facetas de una misma sensibilidad artística, que, al relacionarse entre sí, se potencian mutuamente en su escritura, siempre dispuesta a acoger la distancia infinita del otro. Si el lenguaje poético se caracteriza por su enorme poder de encarnación ("la esencia

\footnotetext{
1 Recibido: 7/VI/2010 Aceptado: 23/VII/2010
} 
del lenguaje es amistad y hospitalidad", señala Lévinas en Totalidad e Infinito), nada mejor que detenernos en una palabra como la de Crespo, que en su esencialidad misma es a la vez acogida y apertura. Sólo desde esa receptividad hospitalaria de una escritura múltiple, cuya variedad de registros constituye su fundación justificadora, podríamos iniciar su despliegue interpretativo, que aporta más de lo que contiene y que, por ello, debe sustraerse a toda tematización. A esta dialéctica tan significativa entre la apertura y el recogimiento, entre la atención prestada a distintas lecturas y su capacidad de interiorizarlas, no fue ajena su dilatada experiencia como profesor de literatura comparada, que le permitió alejarse de las fórmulas consabidas y alcanzar una radical profundidad. Esta precedencia del acogimiento, donde la palabra se configura como morada, es tal vez una de las marcas más visibles de su escritura, que al articular en sí mismas diversas experiencias, al acogerlas en su alteridad, encierra más de lo que a simple vista deja percibir².

Para un poeta como Ángel Crespo, que se da a conocer en el ambiente sombrío de la inmediata posguerra, la afirmación de su identidad, de su voz propia, depende más que nunca de la calidad de su expresión, de un lenguaje renovador que, apoyándose en las experiencias vanguardistas, fuese capaz de sacar a la poesía española del realismo prosaico entonces dominante y abrirla a un tipo de poesía experimental, de intención revolucionaria, capaz de generar por sí misma una verdadera transformación. Si como señaló Brecht la crisis de expresión suele reflejar una crisis de valores, se entiende la pregunta de Crespo (“¿cómo puede facilitarse un cambio en las circunstancias sociales con una técnica conformista?"), en un momento dominado por la estética del realismo social. En realidad, este deseo de salvación por la palabra, que nunca lo abandonará, había empezado ya antes con la revista Deucalión (1951-1953), en cuyo primer número, a modo de manifiesto, hay una voluntad de conectar la cultura española con la tradición internacional y de volver a situar a nuestra poesía en la modernidad anterior a la guerra civil. Ya en el primer número de 1951 aparece esta declaración: "Reunimos aquí los deucaliónicos frutos. Queremos dar a luz en estos cuadernos todo lo que trascienda sentido salvador". Como sucede en el mito griego, "los deucaliónicos frutos", nacidos del diluvio, que simboliza el castigo de la trivialidad en épocas de decadencia cultural, sirven para renovar las formas gastadas, pues el destino de todas las formas es disolverse a fin de poder reaparecer. En este contexto de renovación, del que también se hacen eco El Pájaro de Paja (1950-1954), Poesía de España (1960-1963) y Revista de Cultura Brasileña (19601972), se inscriben los primeros ensayos de Ángel Crespo. Los cuales, en sintonía

2 El texto de Gil de Biedma aparece incluido en el volumen de homenaje, Textos para Ángel Crespo, Diputación de Ciudad Real, 1986, p.114. En cuanto a la hospitalidad del lenguaje poético, que corresponde siempre a una espera, a una disponibilidad desprovista de cualquier intención, remito al ensayo de J.Derrida, Adiós a Emmanuel Lévinas. Palabra de acogida, Madrid, Trotta, 1998. 
con la poesía, se caracterizan por una búsqueda de la trascendencia, cuyas raíces hay que buscarlas en la tradición esotérica y espiritualista, seguida por Valle-Inclán y Juan Ramón Jiménez en la primera mitad del siglo XX, y que Crespo compartió con otros compañeros de generación, como Juan Eduardo Cirlot y Carlos Edmundo de Ory, frente al materialismo existencialista entonces vigente. Precisamente, si algo revelan los ensayos de Poesía, invención y metafísica (1970), a pesar de su diversidad, es una preocupación por la renovación del lenguaje poético, el intento de abrir brecha en lo real mediante el conocimiento, el carácter de hallazgo o descubrimiento que debe tener toda actividad poética ("Todo lo dicho hace que la labor del crítico de poesía haya de situarse en el plano de los principios antes que en el de los sistemas. Porque los sistemas son ordenación de informaciones y sólo en casos excepcionales se convierten en nueva información, son capaces de crear una forma informativa. Y la poesía, desde luego, es de por sí asistemática, preocupada siempre por sus descubrimientos", escribe Crespo en el prólogo que da título al libro). Desde el intento de lo poético por unificar dos realidades, lo inmediato y lo trascendente, se aprecia mejor la continuidad de la poesía de Eduardo Chicharro, uno de los fundadores del postismo, movimiento artístico de vanguardia que se sustancia en la defensa de la imaginación creadora como forma de potenciar lo que es irreductible a la clasificación, en donde la propuesta transformadora, abierta a continuas contradicciones, se refleja en un discurso dialéctico, que traduce el conflicto entre la tradición y la novedad. Así lo expresa Crespo al final de su ensayo "La poesía de Eduardo Chicharro", sujeto a variaciones desde su publicación en 1961, en el que la palabra, liberada de la convención, surge con la tensión dialéctica de la interioridad dramática:

\begin{abstract}
Ahora bien: sería injusto afirmar que la poesía de Chicharro se queda en puro y simple experimento formal, entre otras cosas, porque fondo y forma son absolutamente inseparables. Una intención salvadora, una búsqueda -jtan meritoria-! del optimismo, partiendo del drama interior (y exterior) que ya conocemos, le confieren un valor de humanidad y desesperado entusiasmo que llega con frecuencia a conmover las raíces de nuestra sensibilidad de hombres civilizados con su fulgurante belleza formal y sus deseos de trascendencia. La lucha contra la repetición de una tradición que sin embargo se ama, pero se sabe insuficiente para resolver los problemas planteados al hombre contemporáneo, da un carácter dramático y revelador a los poemas de Eduardo Chicharro.
\end{abstract}

En analogía con el surrealismo, movimiento revolucionario tanto en la moral como en la creación, el lema del postismo ("matar prejuicios"), fundándose en una ruptura de códigos mediante la elaboración de un lenguaje sorprendente, se revela como el medio más eficaz de mostrar las relaciones profundas. Lo que en el postismo se rechaza, en nombre del "experimento formal", es la noción aceptada de una tradición repetitiva ("La lucha contra la repetición de una tradición que sin embargo se ama"), la redundancia de una tradición transmitida y mecanizada, que desde su 
modificación hace posible un nuevo modo de percibir la realidad. Es sobre este código de lo aceptado sobre el que se destaca el postismo, con ánimo de romperlo, y dentro de él, la obra poética de Eduardo Chicharro, que si por algo se caracteriza a lo largo de su evolución, desde Las Patitas de la Sombra (1945), libro escrito en colaboración con Carlos Edmundo de Ory, hasta Cartas de Noche (1950-1964), pasando por Sonetos (1945-1947), Tetralogía (1948-1950) y Música Celestial (1947, revisado en 1959), es por una defensa a ultranza del ingenio verbal, visible en el uso de repetidas aliteraciones, una sintaxis bastante distorsionada, las licencias métricas y de composición, que contribuyen al juego de la sorpresa, lo mismo que la coexistencia de arcaísmos y neologismos, y los símbolos mitológicos, con el que se busca una evasión de la realidad a través de la expresión estética. Dicha "intención salvadora", ya presente desde el romanticismo, supone un intento de llevar el lenguaje hasta los límites de lo posible, de convertirlo en propuesta estética de una belleza ideal ("con su fulgurante belleza formal y sus deseos de trascendencia"), que se sobrepone siempre a la dramática realidad. Lo cierto es que Chicharro, seguro de su voluntad de forma, nos ofrece un "lenguaje secreto", forjado entre la pintura y la alquimia, que, dentro del sincretismo renovador del postismo, lo sitúa en otra dimensión estética, más audaz y menos mimetizadora, haciéndose distinto y reconocible en un contexto de irracionalidad ${ }^{3}$.

Ángel Crespo escribió dos textos autobiográficos: "Mis caminos convergentes", aparecido en el Suplemento que la revista Anthropos dedicó monográficamente al poeta en junio de 1989, integrado más tarde en Con el tiempo, contra el tiempo (2005), y Los trabajos del espíritu (1999), diarios escritos en diversos lugares, que recogen los años 1971-1972 y 1978-1979. Por contener ambos textos anotaciones sobre la poesía y la propia arte poética, se convierten en puntos de referencia indispensables en su trayectoria literaria. Dentro del segundo, al referirse a su estancia en Suecia, a la espera de su visado permanente en los Estados Unidos, nos dice el escritor manchego el 24 de julio de 1971: "Por otra parte, y haciendo balance del año casi completo que estoy aquí, no puedo quejarme: he aprobado todas las asignaturas del doctorado, he dado dos seminarios, tengo muy avanzados los trabajos de documentación para mi tesis sobre El moro expósito, he leído mucho -sobre todo lecturas sobre la Edad Media-, he refundido toda mi poesía en el libro En medio del camino, he escrito poesía nueva, he traducido a Dante y a otros poetas y he terminado la traducción de Palmario". Bajo tales palabras, que traslucen una intensa actividad creadora y crítica, no deja

3 El ensayo de Crespo apareció publicado por primera vez en Miscelânea de Estudos a Joaquim Carvalho, número 6, Biblioteca-Museu Joaquim de Carvalho, Figueira da Foz, 1961, pp.557-586. Sobre su forma de composición, basada en una ética de "la negación y la renuncia", remito al ensayo de P.Gómez Bedate, "La poesía de Eduardo Chicharro", en Poetas españoles del siglo XX, Madrid, Huerga y Fierro, 1999, pp.146-163. En cuanto a la renovación del postismo, tengo en cuenta el trabajo de J.Pont, El postismo. Un movimiento estético-literario de vanguardia, Barcelona, Edicions del Mall, 1987. 
de resultar sorprendente su admiración continuada por el espíritu liberal de Ángel de Saavedra, que constituyó tal vez el nervio más profundo de nuestra tradición romántica. En una época de constantes alternancias, como lo fue el romanticismo en España, el carácter conciliador y moderado del Duque de Rivas le hizo pasar sin traumas de un exaltado liberalismo juvenil a un conservadurismo reaccionario en la madurez, de manera que, al examinar su trayectoria, es el romanticismo español, cuya verdadera naturaleza intentó compaginar los sentimientos patrióticos con los principios liberales de la Constitución de 1812, el que se pone a prueba. Lo que más tarde se ha llamado una "transición pacífica", expresión que en los años del decenio negro fernandino servía para designar a los intelectuales que rechazaron la ideología del despotismo ilustrado para adherirse a las doctrinas progresistas, se convirtió con el tiempo en fórmula retórica para aludir a un tono vehemente en política y a una dicción ornamental en literatura, según refiere Alcalá Galiano en sus Memorias, de modo que, durante aquel tiempo del exilio al que le llevó la persecución fernandina, Rivas se esforzó por adoptar los poemas narrativos de Vigni o Byron al romance del espíritu nacional, siendo esta mezcla de narratividad y lirismo la que va a dar consistencia a sus obras dramáticas. Así, El moro expósito, impreso en París en 1834, ilustra esta tendencia sincrética, característica del romanticismo español. Refiriéndose a su composición, señala Ángel Crespo:

El moro expósito es un poema sobre la Providencia cristiana, y los elementos de su estructura se organizan rítmicamente en torno de su acción vindicativa y restablecedora de la justicia. La Providencia es presentada como la acción previsora y compulsiva de los Cielos, es decir, de Dios, para la que no existen obstáculos, aunque el libre albedrío del hombre pretenda oponérselos inducido por sus mal encaminadas pasiones. Junto a la Providencia actúa una fuerza ciega, designada en el texto con los nombres de "suerte" y "fortuna", cuya acción contradice a veces los designios providenciales, pero que termina por ceder necesariamente a ellos. La lucha entre ambas fuerzas crea en el texto un plano suprahumano que lo carga de sentido y explica y justifica cuanto narra el poema.

Del culto al texto dramático, vigente durante los Siglos de Oro, se pasa a la concepción del teatro como espectáculo en el Romanticismo. Este significativo cambio de lo textual a lo escenográfico, además de modificar las relaciones entre Romanticismo y teatro, basadas en un trasfondo de carácter liberal conservador, tanto en lo político como en lo literario, determinó, en muchos casos, un romanticismo tradicional en el fondo, en los asuntos tratados, y revolucionario en la forma. Esto es lo que ocurre, en cierta medida, con El moro expósito, obra que, si bien en cuanto al enfrentamiento entre la Providencia cristiana y la fortuna pagana ejemplifica la doctrina tradicional ya desde Dante, según la cual la fortuna aparece como ministro de la Providencia, por eso se dice aquí que "termina por ceder necesariamente a ellos", la forma en que se presenta 
esa "lucha entre ambas fuerzas" es sorprendentemente moderna. Lo prueban, entre otros recursos, la abundancia de escenas costumbristas, cuya ambientación sirve para caracterizar mejor a los personajes; la adecuación del romance endecasílabo al tono narrativo, que logra salvar las frecuentes interrupciones; el uso de contrastes entre lo real y lo ideal, dispuestos para captar la atención del lector; y la presencia de imágenes visuales y objetos simbólicos, entre los que destacan los siete cipreses plantados por Zaide en memoria de los Infantes de Lara o el anillo que pasa de mano en mano, que tienden a reforzar el dramatismo de la narración, todo lo cual revela una conciencia escenográfica que antes no se había dado con la misma intensidad. Aunque el análisis de Crespo se oriente preferentemente a la estructura profunda de la obra, no por ello deja de fijarse en estos aspectos innovadores, hasta el punto de que, a partir de su análisis, esta obra dramática ha empezado a leerse de forma distinta. En realidad, la divulgación que hizo Böhl de Faber de las ideas romántico-conservadoras de los hermanos Schlegel, que consideraban al romanticismo español como mezcla cultural de lo medieval y lo barroco, ha impedido tener en cuenta, sobre todo en lo formal, los progresos realizados en otros ambientes europeos, como el francés, respecto a las nuevas ideas sobre la representación dramática, según vemos en el prefacio al Cromwell (1827), de Víctor Hugo, expresión del "romanticismo actual" y que sin duda Rivas conocía. Mientras en la crítica romántica española no se produzca una sustitución de la "poética histórica", establecida a partir de la precariedad burguesa, por la búsqueda de un nuevo lenguaje, que dramáticamente implica un estudio a fondo de la escenografía y la representación teatral, continuaremos sin salir de la tópica reiteración de las fórmulas heredadas ${ }^{4}$.

La obra de arte es residual y lo que queda de ella es el alma que la ha hecho ser. En el empeño de expresar su visión de la realidad trascendente, Juan Ramón, Dante y Pessoa constituyen el núcleo fundamental de las preocupaciones artísticas de Ángel Crespo. De ellos aprendió que la calidad de la escritura poética depende de su capacidad de transmitir el misterio que envuelve nuestra existencia. Porque sólo en la escritura puede el poeta hacer visible el misterio de las cosas. En un poeta tan marcado por la realidad sensorial, como lo fue Juan Ramón Jiménez, la trascendencia de la palabra empieza en lo visual y termina en lo poético. Dado que todo lo real es a la vez físico y metafísico, esa presencia de lo ausente, que es lo que hace que la pintura y la poesía sean las artes más parecidas, es la que revela la dimensión trascendente

4 Para una revisión histórica del Romanticismo español, es importante el estudio de Philip W.Silver, Ruina y restitución: reinterpretación del romanticismo en España (Madrid, Cátedra, 1996), aunque se trata de un estudio orientado hacia la lírica y demasiado condicionado por el trabajo de Paul de Man, The Rhetoric of Romanticism (Columbia University Press, 1984). Desde el punto de vista dramático, me parecen más valiosos los trabajos de E.Caldera, sobre todo, El teatro español en la época romántica, Madrid, Castalia, 2001. 
del hombre y la que da sentido a la palabra. A la luz de esta relación, su obra Juan Ramón Jiménez y la pintura (1974), presentada por Crespo en la Universidad de Puerto Rico para obtener el grado de Maestro en Artes durante el curso académico de 19691970, es una llamada a participar en la unidad de la experiencia artística, con la cual comienza la posibilidad de la belleza. La serie de variantes que Crespo registra en el poema que comienza "Sé que mi obra es lo mismo", del libro Belleza (1923), no hacen más que incidir sobre la visión sinestésica de la poesía, de la que nos deja este breve apunte final:

La proposición de sustituir la palabra "creador" por "pintor" nos parece acertadísima, ya que enlaza perfectamente el sentido del último verso del poema con el de los dos primeros y acentúa -lo que, como vemos, no se había escapado a Juan Ramón- la íntima unión de poesía y pintura en su obra poética. No vamos a entrar aquí -pues se saldría del propósito y límites de este trabajo- en una exégesis comparativa de la primera y las posibles versiones posteriores de este poema juanramoniano. Ello puede ser objeto de un trabajo posterior. Baste, para nuestros propósitos actuales, con afirmar que, por todo lo dicho, por algo de lo que se dirá y por el irrefutable testimonio de este poema, la obra poética de Juan Ramón Jiménez puede -y debe- ser considerada como una gran sinestesia pictóricopoética.

Desde antiguo, más en Oriente que en Occidente, la pintura ha estado unida a la música. En China, por ejemplo, las artes no están desligadas, sino que un artista es a la vez poeta, calígrafo y pintor, aprovechando esa relación para forjarse un lenguaje propio. También Juan Ramón, en uno de sus textos más citados, muestra este sentido integrador: "Primero se despierta en mí el amor a la pintura. Luego, a la poesía. Luego a la música. (A la pintura: de los primeros años de la niñez a los 15 o 16 . A la poesía: de los 15 o 16 en adelante: A la música: de los veinte en adelante). Luego: Primero: Disminuye el amor a la música. Luego, a la pintura. Aumenta siempre el amor a la poesía (y literatura) como arte completo". En su afán de fundirse con lo otro, el poeta andaluz echará mano de "la íntima unión de poesía y pintura" para expresar la totalidad de la experiencia en sus libros finales. Sin embargo, esta consideración de la obra creativa "como una gran sinestesia pictóricopoética", en donde la sinestesia, de acuerdo con el impresionismo simbolista, en el que empezó a formarse Juan Ramón, sirve para explorar toda la vida sensible, es lo que da a su lenguaje poético una garantía de identidad y de permanencia. El hecho de que en sus últimos años aumente "el amor a la poesía como arte completo", que en el fondo refleja la interacción del individuo y el mundo, es lo que convierte a la escritura en un sistema de correspondencias y al poema en un objeto ritual, en que palabras y símbolos, al ofrecernos un proceso de fusión del hombre y el cosmos, abren un tiempo nuevo, destinado a todas las metamorfosis. La unidad de pintura y poesía, que tal vez alcanza su máxima expresión en los años de su estancia en Moguer (1906- 
1912), no sólo afecta a obras tan significativas como Platero y yo (1912), el Diario de un poeta recién casado (1917) y Belleza (1923), sino que permite una mayor compenetración con la naturaleza, con la esencia de las cosas, en su etapa final, que comienza con $\mathrm{La}$ estación total (1923-1936). La depuración de lo esencial, iniciada a partir de Eternidades (1918), hace que sólo queden en la escritura juanramoniana palabras llenas, llevadas por el color y el ritmo5.

En su ensayo "Lo que Dante significa para mí", que data de 1950, T.S.Eliot afirma: "La clase de deuda que tengo contraída con Dante es de las que van acumulándose, no de las que se limitan sólo a un período u otro de la vida". Pocas palabras como éstas podrían ser aplicadas a la relación de Crespo con el poeta florentino, pues desde que emprende su estudio y traducción, a partir de 1970, dicha relación no ha hecho más que intensificarse a lo largo de los años. Esta experiencia acumulativa, que afecta tanto a la sensibilidad como a la expresión, forma parte de un proceso de transformación, sobre el que está construida toda la Comedia y del que participa el propio poeta en su paso a través del Purgatorio. Por eso, en su estudio Dante y su obra (1979), la metáfora de la crisálida apunta directamente a una estética de la metamorfosis, según la cual la poesía se muestra como el viaje más profundo entre lo visible y lo invisible, entre la muerte y la resurrección:

Cuando Dante y Virgilio llegan al Purgatorio, Catón hace que el guía lave la cara a su discípulo y le ciña un junco, símbolo de humildad, a la cintura. Este rito purificador tiene la virtud de hacer que cuanto más asciende Dante por la montaña del Purgatorio, más leve se le haga el camino. En realidad, el poeta va a resumir en su persona la historia completa de la metamorfosis que se opera en las crisálidas del reino de la penitencia. Su estado no es ya el de lucidez permanente -mezclada con algunos desvanecimientos momentáneos y comprensibles- de que disfrutó en el Infierno: ahora se siente intranquilizado por sueños simbólicos y extrañas visiones. Cuando llega ante el ángel guardián de la puerta que da acceso a los siete círculos, éste le imprime siete Pes en la frente, en representación de los siete pecados capitales. Así se inicia la transformación del poeta, cuyos efectos contemplaremos en el Paraíso. Cada vez que abandona uno de los círculos de la purificación, un ángel bate su frente con las alas y le borra una de las letras: es el signo exterior, en la crisálida de Dante, de la maravillosa metamorfosis que se está operando en su interior.

En un tiempo de crisis como el nuestro, ausente de dioses y desprovisto de mitos, el hombre no puede vivir sin ellos. Por eso aquí, la metamorfosis que

\footnotetext{
5 El contacto de Crespo con la obra de Juan Ramón ha sido siempre constante, tanto en lo que se refiere a las ediciones como a los textos. Para la relación del poeta andaluz con el impresionismo, remito al conocido ensayo de R.Lida, “Sobre el estilo de Juan Ramón Jiménez", en Letras Hispánicas, México, FCE, reimpresión de 1981, pp.165-178. En cuanto a la belleza como realidad ideal, en cuya consecución juegan un papel destacado tanto la pintura como la música, véase mi ensayo "El sueño de la belleza en Juan Ramón Jiménez", en El instante azul. Estudios sobre Juan Ramón Jiménez, Madrid, Ediciones Endymión, 2007, pp.283-304.
} 
experimenta Dante en su paso por el Purgatorio, estado intermedio entre el Infierno y el Paraíso, es un movimiento creativo de renovación continua, al que alude tanto la metáfora del viaje como el símbolo de la crisálida, de la oruga que se transforma en mariposa, que al ser aplicado al propio poeta ("de la maravillosa metáfora que se está operando en su interior"), afecta al lenguaje poético mismo ("Así se inicia la transhumanización del poeta"), en donde el verbo transhumanar, como neologismo para expresar lo que está más allá de lo humano, viene motivado por una visión o experiencia interior que había transformado su ser. Al destacar este proceso de transformación en la Comedia, que el propio Dante había descubierto leyendo las Metamorfosis de Ovidio, lo que intenta Ángel Crespo es hacernos ver que la poesía, en cuanto nos permite pasar de un estado a otro, es la ciencia de la revelación de lo desconocido, de la "des-ocultación del ser", como había señalado Heidegger, que la palabra poética es errante por naturaleza y que exige ser continuamente redefinida ${ }^{6}$.

La influencia de un sistema de pensamiento, cuando es realmente vigorosa, irradia desde un centro a varios puntos posibles, lo cual hace que éstos reproduzcan, en distintos grados, lo más esencial de aquél, estableciendo, a partir de ese núcleo central, una serie de afinidades que son impulsadas por un espíritu común. Sea como fuere, lo cierto es que en la época en la que Crespo se dedica al estudio y traducción de la Comedia, esa estética de la metamorfosis, de raíz iniciática, se traslada a otros ensayos del mismo momento histórico, cuya similitud de expresión revela una cierta comunidad de pensamiento. Eso es lo que ocurre con los dos ensayos dedicados a Jorge de Sena, en donde la actividad transformadora del lenguaje poético se revela como clave de su pensamiento. La función de la poesía es transformar el mundo, de ahí que el carácter revolucionario de la actividad poética haya sido comparado con la transformación de la operación alquímica y, a través de ella, con el realismo mágico, entendido éste como sublimación o trascendencia de lo humano, la cual implica una ascensión del hombre a la inmortalidad. De acuerdo con la tesis alquímica, según la cual el hombre es un microcosmos en que se actualiza el universo, la vida no tiene límites y el poeta, al buscar lo eterno en esta vida, pasa por un proceso de iniciación en el que se reconoce inmortal. La poesía es así un arte de iniciación, que nos invita a una experiencia muy intensa, y de él habla Crespo al referirse a la poesía de Jorge de Sena:

\footnotetext{
6 El ensayo de Eliot sobre Dante, que en forma de Disertación fue dado en el Instituto Italiano de Londres, el 4 de julio de 1950, aparece recogido en Criticar al crítico y otros escritos, Madrid, Alianza, 1967, pp.165-178. En cuanto a la transformación en la escritura de la Comedia, que responde a un fondo propiamente esotérico o iniciático, tengo en cuenta, entre otros, el estudio de R.Guénon, El esoterismo de Dante, Barcelona, Paidós, 2005. Respecto al símbolo de la crisálida, que tiene un carácter transformador, véase el trabajo de R.Metzner, Las grandes metáforas de la tradición sagrada, Barcelona, Kairós, 1988, pp.15-38.
} 
En la poesía -qué duda cabe-, en su resplandeciente claridad, la iniciación, lo iniciático, juega un papel decisivo que, por desgracia, ha sido olvidado por muchos lectores, aunque jamás por los verdaderos poetas. Porque -digámoslo de una vez- la poesía no es otra cosa que pura metamorfosis -como la misma lengua, cuando es creadora, cosa olvidada por la mayor parte de los lingüistasy metamorfosis no es otra cosa que cambio de forma: de forma, pero no de substancia. Este es el verdadero misterio de la poesía, lo que suele ser calificado de magia, de esoterismo poético. Por lo demás, lo que la poesía pretende, como todas las metamorfosis, es revelar la verdadera naturaleza, es decir, la naturaleza oculta de las cosas, que no son símbolos de realidades superiores a ellas, como quiere el simbolismo, sino realidades que no se muestran a la mirada superficial ni se entregan a las manipulaciones torpes, incluidas las que tratan de dignificarse bajo los nombres de ciencia objetiva, pues sólo es capaz de revelarlas la palabra poética.

La palabra poética, en cuanto llega a todas las capas del lenguaje, tiene una función purificadora y reveladora. El propio Crespo, en su ensayo "Fidelidad e independencia de Jorge de Sena”, publicado en 1979, había dicho: “Lo más importante de entender en esta poesía es, a mi juicio, su capacidad de transformación de la realidad en mensaje de liberación, en el sentido de trascender lo real para convertirlo en una suprarrealidad, no al modo del surrealismo, sino penetrando más profundamente en ella mediante la superación de sus apariencias". En la poesía moderna, que ciertamente inaugura Baudelaire, la palabra hace transparente aquello que se oculta bajo la superficie. De ahí que en este fragmento, que es continuación natural del primero, la metamorfosis vaya asociada a un cambio de forma ("de forma, pero no de substancia"), aclara el poeta manchego, y el misterio de la poesía sea "calificado de magia, de esoterismo poético". Si lo mágico forma parte de un ritual susceptible de ser expresado simbólicamente, entendiéndolo como representación de una realidad cuyo sentido se ha perdido, entonces lo poético se integrará en ese mismo ritual, pues todo rito, en esencia, reproduce la creación. Desde este punto de vista, el proceso simbólico de la operación alquímica, mediante el cual se buscaba la iluminación y la salvación, no sería distinto del fuego destructor de la palabra poética, cuya iluminación se alcanza mediante la reconciliación de órdenes antagónicos ("El diamante es frío, pero es obra del fuego y de su aventura habría mucho que hablar", escribió Machado en Los complementarios). Al convertir la práctica alquímica en poética, pues ambas buscan regresar a la indiferenciación primordial, nada mejor que acudir a la imagen de "la concha bivalva", que ha sido considerada como símbolo de la fecundidad y a la que se refiere el mismo Sena en el "posfácio" de Metamorfoses, para expresar, con el elixir de la piedra filosofal, la forma de vencer a la muerte. El poeta, a imitación del alquimista, trataría de alcanzar el centro del mundo, convirtiendo lo material en 
espiritual, y su palabra, de naturaleza simbólica, comporta menos una ciencia que un conocimiento ${ }^{7}$.

En su libro incompleto Sobre Iberia y el iberismo, Fernando Pessoa defendió un proyecto común de cultura ibérica, anterior a la latina, afirmando que "el espíritu ibérico es una fusión del espíritu mediterráneo con el espíritu atlántico". Lo que bajo tales palabras se pone de relieve, en un momento de exaltación del Quinto Imperio, es la integración de los distintos pueblos ibéricos en un ámbito más amplio que el peninsular, asegurada por la unidad lingüística, que aloja a su vez una rica diversidad. Y así como en nuestro caso tenemos que remontarnos hacia la lengua del siglo XVI, la de Juan de Valdés, fray Luis de León y Juan de la Cruz, que nos une al español de América y al de la diáspora sefardí, en el caso portugués nos lleva hacia un inmenso imperio colonial, cuya dispersión hizo más necesaria la unificación del espíritu nativo, concentrado en la actitud vital de la saudade, que, en su unidad nostálgica de pasado y futuro, de estar cerca y lejos al mismo tiempo, ha servido para modelar el alma portuguesa, sostenida desde los tiempos de Gil Vicente, en la armonización de lirismo y sátira. De ahí que, en su ensayo "La sabiduría portuguesa", de 1994, al tratar de explicar su constante amor por Portugal, señale Ángel Crespo: “Una de las primeras ha sido esa aristocracia espiritual que permite al país y a sus gentes ser suavemente enérgicos, contenidamente apasionados, sabiamente ingeniosos e idealmente realistas". Quien escribe estas palabras demuestra un hondo contacto con la literatura portuguesa, que ya había comenzado con la Antología de la nueva poesía portuguesa (1961) y proseguido con Antología de poesía brasileña (1973) y Antología de la poesía portuguesa contemporánea (1982), además de sus estudios particulares sobre Oswald de Andrade, J.C. de Melo Neto, Fernando Pessoa, Jorge de Sena y Eugenio de Andrade. Precisamente, a este último dedicó Crespo varios trabajos, entre los que destacan Cartas a Eugenio de Andrade (1979), por parte de Luis Cernuda, Antología poética (1940-1980), publicada en 1981, y Vertientes de la mirada y otros poemas en prosa (1981). Para Crespo, la relación profunda con la poesía de Eugenio de Andrade, abierta a la revelación de una palabra sencilla y transparente, le sirvió de eficaz trasvase a su propia estética, nunca desprovista de la presencia de lo sensible. Por eso, en

\footnotetext{
A Jorge de Sena (1919-1978), dedicó Crespo dos ensayos: "Fidelidad e independencia de Jorge de Sena", publicado en Nueva Estafeta, 7 de junio de 1979; y recogido en Las cenizas de la flor (1987); y "Notas para una lectura alquímica de las Metamorfoses de Jorge de Sena", presentado al Coloquio en Memoria de Jorge de Sena, celebrado en la Universidad de California, Santa Bárbara, en abril de 1979, publicado en Studies on Jorge de Sena, (eds,) Harvey L.Sharrer y Frederick G.Williams, Santa Bárbara, California, 1981, pp.51-62; y recogido después en la revista Anthropos, 150 (1993), pp.37-41; y en Por los siglos, Valencia, Pre-Textos, 2001, pp.211-223. Para la operación alquímica, remito al estudio de J. Sadoul, El tesoro de los alquimistas, Barcelona, Plaza y Janés, 1976. En cuanto a la noción de realismo mágico en la escritura de Crespo, tengo en cuenta el artículo de J.M.Balcells, "Ángel Crespo en pos del realismo mágico", en Anales de filología hispánica, 2 (1986), pp.127-146.
} 
la introducción a su antología, de 1981, refiriéndose al cuerpo como protagonista ininterrumpido de su escritura, nos dice el escritor manchego:

La rehabilitación del cuerpo en cuanto paradigma e instrumento de la belleza -que va de la mujer desnuda de Juan Ramón Jiménez a los Poemas para un cuerpo, de Luis Cernuda, con todos los matices que los diferencian- es otro de los aspectos fundamentales de la poesía eugeniana. $\mathrm{Y}$ tan fundamental que supone la reivindicación de la libertad mediante la afirmación del propio cuerpo, tanto en relación con lo erótico como en función de comunicación (comunión) con la Naturaleza y en la no menos decisiva de herramienta -moral y espiritual al mismo tiempo- para la exploración y conocimiento del mundo.

Dado que el hombre tiene conciencia de estar vivo, habla con su cuerpo y se siente mortal. En una civilización como la nuestra, que arrastra la milenaria separación entre cuerpo y espíritu, el reconocimiento en los límites de lo corpóreo, de lo único que somos, no debiera ser un acto de represión (“Occidente vivirá bajo el signo no cuerpo", señala Octavio Paz), sino de afirmación vital y creadora, tanto "en función de comunicación (comunión) con la Naturaleza" como en "la exploración y conocimiento del mundo". La múltiple pluralidad de lo que somos se unifica en el cuerpo que la expresa, tan frágil y vivo, de manera que la certidumbre sensible del cuerpo es lo que pone al desnudo nuestra angustia. Debido a ella, se entiende que la formación rural de Andrade, similar a la de Crespo en tantos aspectos, muestre una atenuación de lo conceptual en beneficio de la imagen y que su poesía, desde Las manos y los frutos (1948), no deje de fundirse con la naturaleza. Porque, en efecto, todo cuanto aquí es imagen, la vida, el cuerpo, los sentidos, ocupa siempre un primer plano. Y como ocurre en los seres dotados de amor por la vida, la palabra, sentida como objeto erótico, ocupa todo el tiempo en la escritura ("Como ese olor a lino / que sólo los hombros acariciados tienen / la tierra es blanca y desnuda", leemos en el poema Kérkira"). No le ocurre, pues, otra cosa a la escritura de Andrade, dejada sobre su límite, que tocar el cuerpo errante del lenguaje en busca de su propio rostro. Conocer por el tacto, como en los ciegos, equivale a desentenderse del tiempo, a hacer de la palabra poética la única forma de conocimiento, capaz de iluminar un fondo de realidad oculta ("El acto poético es el empeño total del ser hacia su revelación. Este fuego de conocimiento, que es también fuego de amor, en que el poeta se exalta y consume, es su moral. Y no hay otra", dice Andrade, hablando de su "Poética"). $\mathrm{Y}$ es que su palabra, que se ofrece en permanente contemplación de la vida, no es un cuerpo opaco, sino traslúcido, algo capaz de transformar, como su inolvidable cigarra, la luz en canto ${ }^{8}$.

8 De los poetas del 27, a los que Eugenio de Andrade leyó intensamente, el más admirado fue sin duda Luis Cernuda, para quien lo erótico y lo poético se unifican en el cuerpo del poema. En este sentido, véase mi ensayo "El cuerpo del amor", en Luis Cernuda en su sombra, Madrid, Verbum, 2003, pp.147-170. La rehabilitación del cuerpo es algo que aproxima a las dos escrituras, la de Crespo y la de Andrade, 
En el prólogo a Las cenizas de la flor (1987), que lleva el mismo título del libro y aparece compuesto en forma de diálogo ficticio, nos dice el poeta: "Porque hay quien lee la crítica de poesía más para disfrutar de la pericia técnica del crítico que con el fin de buscar un camino de acceso a las intuiciones y emociones del texto poético". Suele calificarse a esta crítica intuitiva de impresionista, olvidando que, en poesía, es la emoción la que se sobrepone a todo lo demás y la que verdaderamente nos conmueve. De ahí que la emoción, por fijar en un instante la imagen de lo eterno, sea lo que permanece en el fondo de la memoria. Si algo aprendió Ángel Crespo, en su trato continuo con la Comedia de Dante, es que toda obra de arte es una trascendencia sensible o emotiva de lo real. $Y$ ese otro mundo, tan real como el que vivimos, permanece oculto si el arte no lo revela. Y puesto que cualquier época crea un sistema de referencias culturales, que con el paso del tiempo se van convirtiendo en lugares comunes, sólo la experiencia interior, aquella que forma parte de lo que somos y habla a nuestra emoción, escapa a toda posible identificación. Es bien conocida la preferencia de Crespo por los períodos de metamorfosis, como el paso de la Antigüedad clásica a la Edad Media o de ésta al Renacimiento, por eso se alejó de las categorías vigentes en la investigación histórica y se sintió atraído por aquellos momentos en que lo individual se construye a nivel de lo afectivo. Eso fue lo que ocurrió con sus estudios sobre Dante y Petrarca, que vivieron en una época donde se elaboran los fermentos de la futura primavera. Precisamente, al año 1983 pertenecen dos ediciones: la del Cantar de Roldán, atribuido a Turoldo, y la del Cancionero de Petrarca, sobre el que vuelve en ediciones posteriores. Mientras en la primera se dedica a refutar la tesis de Menéndez Pidal en La Chanson de Roland y el Neotradicionalismo y su falta de "sensibilidad poética", en la segunda, producto de amplias lecturas y años de investigación, se detiene en la doble condición de Petrarca, poeta y humanista, que es la que da formación y consistencia a su Cancionero, obra que es desarrollo de su proceso interior y en donde el análisis de los sentimientos, que hasta entonces no se había hecho de forma tan intensa, alumbra un nuevo lenguaje poético, rasgo esencial de todo gran poeta, mediante el cual lo real y lo imaginario sólo se identifican en lo ilimitado de la búsqueda. Aludiendo a esa intensificación de la realidad en la palabra, pues ésta le da la emoción que aquella no tiene, señala el escritor manchego:

Por otra parte, se observa en el Cancionero una tensión entre la libertad de expresión sentimental y las necesidades y cortapisas de la forma artística perseguida por su autor. Petrarca se propuso, en principio, la forma clásica, pero terminó por imbuirle un manierismo que es, no sólo efecto de su maestría, sino también de esta contradicción, en el sentido de que trató de reflejar en sus rimas los matices

según ha visto J.Cerdà Subirachs en su artículo "Eugénio de Andrade y Ángel Crespo: breve recorrido de una empatía", Cuadernos Hispanoamericanos, 684 (junio 2007), pp.47-55. 
más sutiles derivados de una introspección que no es propia de la poesía clásica, más afecta a lo general que a las particularidades personales del poeta.

Una lectura conjunta del Secreto mío y del Cancionero revela el esfuerzo de Petrarca por conseguir un nuevo lenguaje que deje superados los ecos del dolce stil nuovo. Como ese lenguaje se pone al servicio de un proceso amoroso, que va de lo pasional a lo intelectual, lo más visible en la escritura del Cancionero es la serenidad alcanzada a través del contacto con la naturaleza, como sucederá más tarde en las Églogas de Garcilaso, que atempera los ánimos y resuelve las contradicciones, lo cual se refleja en una expresión contenida, que afecta tanto a la estructura orgánica de la obra como a su estilo. Bastaría el soneto CCXXIX ("Canté, ahora lloro, y no menor dulzura / me da el llanto que el canto ya me ha dado"), para darnos cuenta de que ese equilibrio entre llanto y canto, que ya había aparecido en la canción XXIII, donde el poeta se identifica con la amada mediante su conversión en laurel, es el que engendra un estado de serenidad, matizado por la mesura y el rigor de la expresión, como preparación para la muerte de Laura. Escribir para aquietarse, para apagar una ausencia en la que no se reconoce, es lo que lleva a Petrarca a explorar los límites del lenguaje desde una escritura concebida como ejercicio de intimidad ("una introspección que no es propia de la poesía clásica, cuya singularidad refleja una tolerancia de sometido que pasa por ser paciencia de sabio"). Pues la poesía, en su necesidad de expresión más sustantiva, no es más que una ofrenda sostenida de intimidad 9 .

En sus Páginas Íntimas e de Auto-Interpretaçao, Pessoa se define como "un temperamento femenino con una inteligencia masculina", siendo tal dicotomía entre lo sensible y lo inteligible la que engendra una tensión contradictoria, que se refleja tanto en su labor poética, que trata de hacer coincidir lo decible con lo indecible, como en su visión amorosa, considerando al amor como "el horror metafísico del Otro" y a la amada como realidad misteriosa. Si tenemos en cuenta que el sentimiento poético, antes de serlo en inteligencia lo es en sensibilidad, o mejor, que se organiza en la sensibilidad antes de ser expresado, se entiende la analogía entre la experiencia poética y la experiencia amorosa, pues ambas buscan la otra mitad que les falta. Y esa otra mitad inalcanzable produce, en el que la padece, una angustia nostálgica,

\footnotetext{
$9 \mathrm{Al}$ asumir Petrarca en su Cancionero las dos tradiciones, la poesía trovadoresca y la del dolce stil nuovo, no sólo renueva el lenguaje de la época, demasiado apegado a las formas de la retórica clásica, sino que además lo dota de una intimidad, acaso como respuesta al deseo de escapar al discurso escolástico, frío e impersonal, que va a ser característica de la lírica posterior. La insistencia en el amor como revelación del ser es la que genera un discurso íntimo, cuyo poder de sugerencia, por haberse formado en lo interior, lo hace más entrañable y singular. Al doble valor del discurso humanista, su enraizamiento en lo concreto y la emoción que hace de ello algo trascendente, se han referido F.Rico, El sueño del humanismo, Madrid, Alianza, 1980; y L.Fernández Gallardo, El humanismo renacentista: de Petrarca a Erasmo, Madrid, Arco Libros, 2000.
} 
de insuficiencia radical por el hecho mismo de no estar, que sostiene la escritura fragmentaria del Libro del desasosiego. Lo que en esta obra singular se muestra es que el amor es una irrealidad que se desea realizar y que ello sólo es posible a través de la máscara, donde el otro finalmente llega a ser. Por eso, al final de su ensayo "La negación del amor en el Libro del desasosiego", incluido en sus Estudios sobre Pessoa (1984), Ángel Crespo nos viene a decir que el rechazo heterosexual de Bernardo Soares se complementa con la aceptación homosexual de Álvaro de Campos, apareciendo lo erótico, en el límite de la escritura, como el conflicto entre lo posible y lo imposible:

Como ya se ha dicho, sería sumamente interesante comparar la negación del amor por parte de Soares con la negación del amor por parte de Fernando Pessoa, pero el objeto de estas páginas -que sólo doy por parcialmente conseguido- ha sido contemplar a nuestro poeta a través de su máscara, de una de sus máscaras, pues ¿no se advierte que, en la propia correspondencia con Ofelia, Pessoa no se despoja de la máscara de su escritura ortónima sino para cubrirse con la mucho más elaborada de Álvaro de Campos, cuyas tendencias homosexuales bien pudieran ser la causa de su oposición al amor de que dichas epístolas son testimonio irrebatible?

Suele decirse que la sutileza de la inteligencia paraliza la voluntad. Para un poeta como Pessoa, instalado en la duda ("No me dejes en la duda", pide a la amada en uno de sus últimos poemas), lo erótico, en su interminable peregrinaje hacia lo desconocido, expresa nuestro modo imposible de ser. Y puesto que el erotismo sólo puede vivir desde la paradoja, algo que garantiza la continuidad entre la aceptación y el rechazo, el placer y la negación, es preciso que la palabra, en su necesidad de ser algo otro que ella misma, preserve la tensión de la unidad en la diferencia. La virtualidad de la palabra poética, implicada en la contingencia de lo efímero y abierta a la trascendencia de lo posible, halla su cumplimiento a través del juego mediador de la máscara, la de Bernardo Soares y la de Álvaro de Campos, que no sabe vivir sola y persigue la otra mitad. Mientras se mantiene la contradicción, la tensión perdura. Gracias a la mediación de la máscara, se puede recuperar la otra mitad, pues lo erótico es a la vez nostalgia y búsqueda de la unidad perdida. Por eso aquí, el fragmento seleccionado aparece como algo provisional, según revela la ruptura lingüística del guión o paréntesis ("-que sólo doy por parcialmente conseguido-"), y la simulación de la máscara, su forma velada y transversal, contribuye a la indiferenciación de lo real y lo irreal, puesta de manifiesto por la respuesta afirmativa de la interrogación retórica. Si la propuesta revolucionaria de Pessoa fue su intelectualización, el intento de sublimar la ausencia de lo que nos es propio, nada mejor que la máscara, convertida en forma de intercambio, para liberar al amor de sus contradicciones, dándole una 
posibilidad mediante la negación. El arte de la desaparición se hace así ritual de la transparencia ${ }^{10}$.

Del contacto de Ángel Crespo con la obra de Fernando Pessoa, el poeta que rompe la pasión moderna por la identidad a través de los heterónimos, se desprende una poética de la destrucción, en donde la desaparición del sujeto es condición de toda escritura, que se inscribe en la tradición de la ruptura y responde a un reconocimiento de la situación trágica del hombre. Haciendo de la disolución una forma de apertura, Crespo logra darnos, en los ensayos que configuran Las cenizas de la flor (1987), una visión de su actividad poética. Valiéndose de esa dialéctica entre lo que se destruye y lo que se crea, presente en los dos símbolos del título y que aparece ya en el poema "Bizancio" de Yeats, el escritor manchego piensa que la experiencia de las ruinas, huellas de lo que queda, sigue siendo un decir en cuanto guarda, a través de la palabra, una relación con lo vivido. Dentro de la primera parte, aparece el ensayo "Las nueces, la poesía y la cábala", que comienza con estas significativas palabras:

\begin{abstract}
Si se me pregunta en qué consiste la poesía, diré, sin pretender agotar la definición, que en ir cargando a las cosas de significados de los que aparentemente carecen y que, no obstante, se encuentran desde siempre en ellas, en espera de que alguien los descubra y nos ayude, al hacerlo, a comprender al mundo y a comprendernos a nosotros mismos. Estos significados pueden ser puramente estéticos -lo que los justifica enteramente- o pueden tener un carácter más profundamente poético y revelador.
\end{abstract}

La contemplación de las ruinas nos permite entrever un tiempo puro, perdido ya para siempre, cuya recuperación compete al arte y de forma especial a la poesía, que nos muestra la posibilidad de vivir nuestra vida en aquello que es otra, como metáfora que nos libera de lo efímero y nos abre a la naturaleza simbólica del mundo. No hay revelación sin sacrificio, de ahí que aparezca como rasgo esencial de lo poético un estado de disponibilidad ("en espera de que alguien los descubra"), donde lo desconocido se hace inminencia de cuanto puede ser. La labor del poeta es "ir cargando a las cosas de significados de los que aparentemente carecen", de manera que sólo a través de la espera puede llegarse al alumbramiento de lo desconocido, a

\footnotetext{
10 Entre los trabajos de Ángel Crespo sobre Fernando Pessoa, que fueron constantes a lo largo de su vida, destacan tres: Estudios sobre Pessoa (1984), La vida plural de Fernando Pessoa (1988) y Con Fernando Pessoa (1995). Dejando a un lado el segundo, de carácter autobiográfico, es necesario fijarse en los otros dos para ver en ellos una continuidad de experiencias y actitudes. En este sentido, teniendo en cuenta la edición que hace Crespo del Libro del desasosiego en 1984, libro concebido como experiencia del límite, nos sirve para entender mejor el erotismo de sus últimos poemas (Véase el artículo de Crespo "El último amor de Pessoa", Revista de Occidente, 94, marzo de 1989, pp.5-26). Sobre los estudios pessoanos de Crespo, tengo en cuenta, entre otros, los ensayos de J.M.Balcells, "Los estudios pessoanos de Ángel Crespo", Cuadernos Hispanoamericanos, 425 (1985), pp.138-142; y de E.Lourenço, "El Pessoa de Ángel Crespo", Anthropos, 17 (1989), pp.178-181. Si bien ambos deben renovarse a la luz de Con Fernando Pessoa (1995).
} 
esa "otra realidad" de la que nos habla Rimbaud en las Iluminaciones. El poema es el medio de penetrar en esa realidad ignorada, por eso de las dos formas de significación aquí apuntadas, se prefiere la segunda por cuanto hace de la escritura una apuesta por lo absoluto. Si al leer un poema nos vemos sorprendidos por su fondo misterioso, por una experiencia que no se entiende, es porque, en el proceso de búsqueda, escucha y revelación, esa existencia latente, impulso generador del poema, es la que ofrece "un carácter más profundamente poético y revelador". Así pues, podría decirse que el sentido de un poema no se agota en su escritura, que es siempre múltiple e infinita, sino en su expansión hacia lo extraño, en su expresión simbólica, que nos ayuda "a comprender al mundo y a comprendernos a nosotros mismos", a acceder a una nueva dimensión de la vida. Esa distancia que se transparenta en el poema, ese estado de espera o de escucha a que lo otro se revele, es lo que hace posible una visión poética del mundo ${ }^{11}$.

El arte moderno, el que se inicia con las vanguardias al romper el siglo XX, se caracteriza por una inquietud renovadora, en la que conviven la elaboración de formas preexistentes y la creación de otras nuevas, que sólo se realizan, en la "época de la reproductibilidad técnica", como ha señalado Benjamín, a través de la experiencia estética. De tal equilibrio entre lo tradicional y lo nuevo participa la escritura de Gerardo Diego, al que Ángel Crespo dedicó su ensayo “Una figura ejemplar de nuestras letras", con motivo de su muerte en 1987. Después de subrayar en él su objetividad crítica, producto tanto de "la generosidad" frente a la obra ajena como de "la discreción" ante la propia, dos cualidades que, según Crespo, no son frecuentes en la crítica española sobre poesía, y su formación dentro del ultraísmo y el creacionismo, sin los cuales no se entiende la generación poética del 27, finaliza su ensayo con las siguientes palabras:

Otras muchas son las remuneradoras sorpresas que nos reserva sin duda el cada vez más perentorio estudio de la obra ejemplar de Gerardo Diego. Y no sería la menos significativa de ellas la comprobación de la influencia que, a partir de los años setenta, viene ejerciendo en nuestra mejor poesía joven la libertad verbal y rítmica de sus versos, así como sus poliédricos y caleidoscópicos enfoques de la historia y de la actualidad de la cultura contemporánea, valores éstos que han permitido comparar a la casi desconcertante variedad de la obra gerardiana con la pintura de Picasso. El santanderino no es inferior en nada al malagueño, puesto que en la obra de ambos prima e impera la imaginación, pero una imaginación

11 En cuanto a la verdadera naturaleza de las ruinas, destinada a captar la mirada de los otros, remito al estudio de M.Augé, El tiempo en ruinas, Barcelona, Gedisa, 2003, pp.21-31. En cuanto al carácter revelador de la palabra poética, que es lo que le da una dimensión sagrada, tengo en cuenta el trabajo de tesis doctoral de J.Ardanuy López, La búsqueda de lo sagrado en la poesía de Ángel Crespo (Barcelona, Universidad Pompeu Fabra, 2003), disponible en Web y cuyas investigaciones han sido incorporadas a su estudio posterior, La poesía de Ángel Crespo (límite, símbolo y trascendencia), Valencia, Pre-Textos, 2004. 
no gratuita, sino coherente y cargada de significado, como producto que es de un prodigioso equilibrio de la sensibilidad y el conocimiento.

Gerardo Diego tuvo siempre una concepción dinámica de la obra de arte y pensó que el poema es una construcción poliédrica que se ofrece al lector. Sólo incorporando la solidez clásica y el ilusionismo experimental en el objeto estético, se pueden conseguir obras de fuerte carácter expresivo, gracias sobre todo al poder de "la imaginación" como fundamento de la creación poética, cuya función es asegurar el "equilibrio de la sensibilidad y el conocimiento", percepción sensorial y construcción mental, sentimiento y pensamiento. La relación que aquí se establece entre el arte poético de Diego y el pictórico de Picasso, no sólo obedece a la estrecha conexión entre las distintas artes durante la época de las vanguardias, resultado de proyectar la realidad más allá de la realidad, sino también a la forma dinámica de la tradición, cuyo poder fecundante sirve para que el misterio de lo ajeno se traduzca en presencia de lo propio. Las analogías que entre ambos artistas pudieran establecerse se reducen, en último término, al papel creador de la imaginación, capaz de convocar por sí misma la presencia del otro, de extraer lo desconocido de lo conocido. Dicha transformación se hace sensible a través del ritmo, que al afirmar la alteridad trascendente mediante el impulso musical, se convierte en fundamento de la creación artística. Precisamente, la vigencia de Gerardo Diego entre los poetas más jóvenes se debe a "la libertad verbal y rítmica de sus versos", a la versatilidad de una escritura, cuya autonomía radica en la pulsión del fluir imaginativo, en una expresión sintética que dibuja, con precisión alquímica, destructora y creadora a la vez, la sensibilidad de una época incierta, caracterizada por la ruptura de códigos. Lo que sus poemas dejan aparecer, tal vez siguiendo en eso a Huidobro, es la realidad como proceso natural en la escritura, el acto creador como una música de fondo ${ }^{12}$.

Decía Walter Benjamín que un acto de creación no tiene prisa, puesto que nos lee y espera el tiempo suficiente para que lo descubra un buen lector. Algo de esto fue lo que ocurrió con el Postismo, movimiento estético de vanguardia, que, desde su aparición en 1945, apostó por una defensa de la imaginación creadora como medio de profundizar en el conocimiento de la realidad. En su ensayo "Mi experiencia postista", de 1989, Ángel Crespo, al reconocer la relevancia que tal movimiento tuvo en su formación artística y los esfuerzos de Chicharro y Ory como "dos únicos

12 La relación de Ángel Crespo con la obra de Gerardo Diego no ha sido coyuntural, sino persistente a lo largo de los años. Un ejemplo de ello es el ensayo de Crespo, "Paralelismos alquímicos en un poema de Gerardo Diego", incluido en Por los siglos, pp.201-210, en donde, apoyándose en los poetas simbolistas franceses, establece un paralelismo entre la alquimia y la estética vanguardista. Para la formación creacionista de Gerardo Diego, mucho más profunda que la ultraísta, véase el estudio de F.J.Díez de Revenga, Gerardo Diego en sus raíces estéticas, Universidad de Sevilla, 2006. En cuanto a la simbiosis de crítica y creación en la escritura de Gerardo Diego, remito a mi ensayo "Gerardo Diego: la lucha por la libertad creadora", en Poetas y críticos del 27, Universidad de León, 2008, pp.155-213. 
pilares fundamentales", destaca la creación de un nuevo lenguaje como signo de universalidad y permanencia:

Aunque políticamente estuviese de parte de los poetas de Espadaña, intuía ya lo que la experiencia postista no tardaría en empezar a confirmarme: que no se puede combatir con eficacia contra los detentadores de una cultura oficial reaccionaria valiéndose de su mismo lenguaje, es decir, aceptando su juego. Había que empezar uno nuevo y ésa fue la posibilidad que no tardé en descubrir en el postismo, movimiento que, al abrirse a las vanguardias europeas, entonces denostadas en España, se había situado desde el principio por encima de lo puramente coyuntural.

El lenguaje poético, al ir en contra de lo explícitamente dicho, es por naturaleza subversivo. Si por algo se caracterizó el postismo, en un momento de oposición a las vanguardias ("entonces denostadas en España"), fue por la defensa de un programa basado en la libertad de la imaginación creadora, que sólo surge si una voz oculta la reclama y se hace visible a través de un nuevo lenguaje ("Había que empezar uno nuevo y esa fue la posibilidad que no tardé en descubrir en el postismo"), capaz de dar respuesta a cierta necesidad de ser uno mismo y de descubrir nuevos territorios de realidad bajo lo que oculta la ideología de la cultura oficial. Hay, por tanto, en la raíz de lo poético un compromiso con lo que existe realmente, que si bien permanece callado, necesita ser dicho. Lo que hay más allá pertenece al ámbito de lo desconocido, de lo sagrado. Tal vez por eso el postismo, debido a su atención por lo que surge en el instante de la creación, fue considerado como un movimiento artístico al margen de la realidad histórica. Sin embargo, el hecho de partir de una tradición reconocida ("Yo parto del romanticismo germano y universal. De la vida teórica y activa del espíritu libre", anota Ory en su Diario), enriquecida más tarde con la lectura de los poetas simbolistas y surrealistas, es lo que da al postismo la posibilidad de entender el lenguaje como una experiencia común entre el hombre y la naturaleza. Si el poema se ilumina por algo que no se sabe decir, la aventura postista se singulariza precisamente por evidenciar que el lenguaje nunca es completo, por habitar en la tensión dialéctica antes que en la síntesis superadora. Lo que queda de ella, a pesar de su brevedad y relativo fracaso, es su expectativa de transformación, la necesidad que siente el poeta de ser único, es decir, diferente, en medio de la vulgaridad reinante ${ }^{13}$.

13 El ensayo de Crespo apareció publicado en la revista Ínsula, 510 (1989), pp.27-28. A él hay que añadir el homenaje que esta misma revista dedicó al postismo en su número 670 (2002), en donde aparecen algunos artículos ciertamente valiosos, como el de J.Pont, "Ángel Crespo en el postismo: claves poéticas", pp.27-29. En cuanto a la valoración del postismo como experimentación lingüística, que según G.Carnero es "su mejor sello de calidad", véase su ensayo más amplio, "Apuntes para la historia del superrealismo en la poesía en español de la alta postguerra", en Las armas abisinias. Ensayos sobre literatura y arte del siglo XX, Barcelona, Anthropos, 1989, pp.337-362. 
La visión de la belleza, de esa otra realidad trascendente e intocable, está siempre más allá de lo histórico, en una distancia entre lo real y lo irreal, que sólo la palabra poética puede recorrer. Acaso por su intento de desenmascarar un tiempo sometido a la falsificación, la poesía de Manuel Mantero ha empezado a reconocerse, en su irreductible individualidad, como una propuesta estética que no va en contra de la conducta moral en que se funda, precisamente porque la acepta como tal. Si en su artículo "La espiral lírica de Manuel Mantero", de 1983, Ángel Crespo había destacado el carácter autobiográfico de su escritura, en su ensayo "Ética y estética en la poesía de Manuel Mantero", publicado en 1991, esa correlación que se establece entre los dos aspectos de una misma actitud vital, entendida como acto de autocreación, se plasma en una escritura que aspira a representarlo todo, en donde el tiempo se siente como la caída de lo que existe, pues la vida se construye sobre la destrucción de la memoria. Desde su primer libro Mínimas del ciprés y los labios (1955-1956) hasta Memorias de Deucalión (1982), pasando por Tiempo del hombre (1959-1960), La lámpara común (1961-1962) y Misa solemne (1964-1966), la escritura poética de Mantero no hace más que representar el juego de vivir, evitando la retórica que se añade a la afectación. Ante una historia irreconocible, notoriamente falseada por años de deformación sistemática, lo que más se aprecia es ese punto de convergencia entre lo ético y lo estético, fruto de una sensibilidad para percibir lo esencial. Refiriéndose a los poemas “Réquiem por Adriano del Valle" y "Vicente Aleixandre cumple sesenta años", de La lámpara común, señala Ángel Crespo:

Estos dos poemas se cuentan, pues, entre las varias alusiones indirectas de este libro a una poética en la que la preocupación ética, lejos de caer en el materialismo positivista, tiende a la superación de lo material en beneficio de un conocimiento de la belleza y de la trascendencia que vehicula.

Cada escritura muestra la faz de su autor. La de Manuel Mantero pone de manifiesto una errancia en el exilio, una búsqueda de la identidad perdida al margen de toda servidumbre, que implica el sacrificio de nuestro ser, mediante el cual nos penetra intacta la vida. Bastaría un poema como "Encuentro de Luis Cernuda con Verlaine y el Demonio", de Misa solemne, sin olvidar que fue Cernuda quien, al hablar de San Juan de la Cruz, considera la obra literaria como "resultado de una experiencia espiritual, externamente estética, pero internamente ética", para comprobar que lo que permanece es lo que se inscribe en la vida, que el arte sólo se alimenta de un sentido de lo trascendente, fundado por la palabra del poeta ("la superación de lo material y lo coyuntural en beneficio de un conocimiento de la belleza y de la trascendencia que vehicula"). De acuerdo con ello, la permanencia de la belleza en la fugacidad de un instante, que tal vez constituye la esencia misma del poetizar, resplandece en la fluidez de la forma musical por donde pasa libremente el pensamiento. Y es que para 
que lo bello exista, para que su sombra se proyecte sobre lo que tiene de instantáneo y frágil, es preciso que la palabra se sienta como un fluir que todo lo unifica, como el movimiento de la vida que se respira y nos mejora ${ }^{14}$.

El arte tiene la virtud de amaestrar el tiempo, de sustraerlo a la historia, en espera de una posible revelación. Uno de esos lugares concretos, donde el arte se basta a sí mismo y donde la palabra alcanza por fin su inocencia, es Italia, que desde 1963 fue para Crespo una especie de "tierra mítica", llena de espíritu, donde la contemplación de la luz se convierte en un modo de acceder al misterio ("Italia supuso para mí algo más profundo que un simple deslumbramiento. A medida que iba respirando su aire, viviendo su arte y soltándome en el uso de su lengua, sentía que una nueva luz hecha, por así decirlo, a la medida de mis ojos, iba iluminando mi pasado y mi presente, no para que yo los repudiase o aceptase, sino para que tratara de interpretarlos", confiesa el poeta en "Mis caminos convergentes"). Esa iluminación se hace visible no sólo en las traducciones de Dante y Petrarca, sino también en su antología Poetas italianos contemporáneos (1994), que revela un conocimiento basado en la experiencia de una prolongada lectura. De los catorce poetas seleccionados, tres le merecen una especial consideración, Giuseppe Ungaretti, Eugenio Montale y Salvatore Quasimodo, que fueron también los que más contribuyeron a la renovación de la lírica italiana de su tiempo a través de un lenguaje hermético, practicado en torno a la revista florentina Campo di Marte, cuya estética, caracterizada por su ruptura y difícil comunicabilidad, hace de la palabra una experiencia enigmática, en la que el lenguaje apunta hacia aquello que puede no ser dicho. Refiriéndose al quehacer poético del primero, a lo que lo hace único e irrepetible, Crespo habla de

Una originalidad que le llevó a romper con el verso tradicional italiano de arte mayor, al que fragmentó en versos de arte menor, llegando a escribirlos de una sola palabra que muestra aislada al mismo tiempo que como parte de un discurso no tradicional, lleno de sugerentes e intrigantes, cuando no misteriosas ambigüedades. Se trata de una renovación formal mucho más radical, incluso por ser más hacedera, que las delas palabras en libertad del futurismo, movimiento con el que colaboró el mismo Ungaretti, puesto que lo que este poeta logró instaurar fue una poética del fragmento como única opción posible de poesía en el universo fracturado en que vivimos.

14 El ensayo de Crespo, "La espiral lírica de Manuel Mantero", publicado en Revista de Poesía e Crítica, número 9, septiembre de 1983, fue recogido en Las cenizas de la flor (1987, pp.229-232); y "Ética y estética en Manuel Mantero" se publicó como homenaje al poeta sevillano en la revista Anthropos, 116 (1991), pp.32-41. A su vez, el propio Mantero ha mantenido una amistad con Ángel Crespo, de la que proceden sus ensayos: “La poesía de Ángel Crespo", Anthropos, 97 (1989), pp.35-44; “Ángel Crespo y la mentalidad de la época", Anthropos, 24 (1991), pp.103-108; y "En Florencia con Ángel Crespo", Quimera, 254 (2005), pp.21-23. 
La palabra poética, que subvierte los límites convencionales del lenguaje, aparece en el extraño espacio del poema como posibilidad de expresar su interioridad. Fueron los Padres de la Iglesia quienes, basándose en la doctrina teológica del Verbo, concibieron la relación entre la Palabra divina y la palabra humana en términos enigmáticos (“Y este es el más grande enigma, que no veamos lo que ver no podemos", escribe San Agustín en De Trinitate (XV, cap.IX, 16), donde el uso paradójico del lenguaje muestra la ambigüedad entre ser y conocer. Si la poesía no es un género, sino una forma de visión, la repercusión que ha tenido la interpretación enigmática agustiniana en la moderna teoría hermenéutica, salvando la distancia de algunas modalidades renacentistas y románticas, evidencia la posibilidad del habla fragmentaria, ya desde Nietzsche, de rechazar lo inmediato y volverse hacia lo ausente. Si el logro de Ungaretti fue "instaurar una poética del fragmento", tal vez como resultado del mundo caótico en el que tuvo que vivir ("Con estos fragmentos he apuntalado mis ruinas", dice Eliot al final de La tierra baldía), es porque el fragmento da el punto en que la revelación de lo poético se produce. Por remitir a un más adentro de sí mismo, el fragmento tiene una posibilidad mucho mayor de abrir más horizontes al lector que el poema extenso. De ahí que los dos únicos versos del poema "Mañana" contengan, en su brevedad constitutiva ("Me ilumino / de inmenso"), toda una poética de la epifanía, pues la palabra poética, a la vez fragmentaria y total, lo que hace es proyectar lo invisible en lo visible, realizar lo integral en la extrema desnudez de su lenguaje ${ }^{15}$.

A medida que Ángel Crespo se aproxima a sus años finales, se hace más intenso en su escritura un ideal común a las diferentes artes, pintura, música y poesía, bajo el que se intuye una conciencia total de la realidad como fundamento de la expresión. Lo que dejan traslucir los ensayos recogidos en Por los siglos (2001) y La invención del poeta (2007), a pesar de su elaboración en momentos distintos, es una evolución que tiende a una mayor sobriedad como resultado de una experiencia largamente acumulada. Su preferencia por el poema breve, que según Poe ha sido el determinante de la modernidad, le ha llevado a practicar una escritura aforística en relación con la poética, tal vez siguiendo el ejemplo del propio Juan Ramón, y en la que se aprecia una convergencia de ética y estética, de pensamiento y expresión (“Con el aforismo he tratado de sintetizar un pensamiento o una intuición que se me escapaban, de

\footnotetext{
15 En cuanto a la repercusión de la interpretación enigmática de San Agustín en la moderna teoría hermenéutica, véase el estudio de H.G.Gadamer, Verdad y Método, Salamanca, Sígueme, 1977, pp.505 y ss. De los poetas hermenéuticos italianos, fue Ungaretti el que más concentró la atención de Ângel Crespo, según podemos ver en su ensayo "Un clásico de nuestro tiempo (Giuseppe Ungaretti)", aparecido en Diario 16, 16 de abril de 1988, y recogido después en El poeta y su invención (Barcelona, Círculo de Lectores, 2007, pp.324-327). En cuanto a la relación de Crespo con Italia, tengo en cuenta los artículos de B.Conti, "Plata en la laguna", En torno a la obra de Ángel Crespo, ACEC, 5 (noviembre 1995), pp.17-20; y de E.Badosa, “La ventura italiana de Ángel Crespo", Quimera, 254 (marzo 2005), pp.24-26.
} 
prescindir del verso y de su fluencia musical para ser más incisivo, más sintético. En la poesía hay versos que se hacen recordar a la manera de los aforismos. Eso demuestra que hay una relación entre una y otra escritura", nos dice en su entrevista “¿Qué es poesía?”). El hecho de que algunos de estos aforismos pertenezcan a una época anterior, la de la revista El pájaro de Paja (1950-1954), hayan formado parte de los libros de poesía Con el tiempo, contra el tiempo (1978) y La invisible luz (1981) y, por último, hayan quedado fuera de la edición de su Poesía (1995), hasta formar una publicación y un género aparte, Aforismos (1997), prueba no sólo su autonomía, sino también el deseo de mantenerlos juntos para no perder de vista la unidad que los integra: la confluencia de pensar y decir. Sólo desde ella se puede expresar la concepción de la poesía como realidad intuida en su propia experiencia. De ahí que la mayor parte de ellos tengan que ver con la intemporalidad de la creación artística, como vemos en "Parábola sola", en donde la continuidad de lo invisible se revela como sustancia misma de lo poético:

La poesía es como un árbol que crece al revés: su copa atraviesa el centro de la tierra y acaba por aparecer en los antípodas, donde parece un árbol cualquiera; por lo que pocos son capaces de llegar hasta sus raíces.

Paul Klee, uno de los artistas más serenos y reflexivos del siglo XX, se sirvió de la parábola del árbol para expresar el florecimiento del yo profundo, que caracteriza al arte moderno. En ella, el poeta se encuentra en la situación intermediaria del tronco, recogiendo lo que sube de las profundidades y transmitiéndolo más lejos a través del aire. Ante la inversión que aquí se produce, pues se va de la copa a las raíces y no al revés, comprendemos que el poeta, como mediador entre la profundidad y la altura, se identifica más con las raíces que con el follaje del árbol, siendo esa formación en lo profundo, marcada en el fragmento por la continuidad de las formas verbales ("atraviesa", "acaba por aparecer"), la que alumbra la naturaleza misma del poema, pues a éste se le capta como génesis, no como mero producto. De esta manera, la dificultad que entraña el descenso a lo profundo ("por lo que pocos son capaces de llegar hasta sus raíces"), pues hace visible una visión secreta, es la imagen misma de la palabra poética, la cual, al retraernos a su absoluta interioridad, nos impulsa hacia el fondo original. Lo que hace este aforismo, desde su brevedad integradora, es reconocer la creación como génesis ${ }^{16}$.

16 Con su libro Aforismos (Madrid, Huerga y Fierro, 1997), Ángel Crespo no hace más que seguir una forma práctica del saber para la vida, de gran vigencia entre los moralistas franceses y españoles de los siglos XVI y XVII, y que cuenta con un amplio desarrollo en nuestra tradición literaria. En este sentido, véase mi ensayo "La práctica aforística de Juan Ramón Jiménez", en El instante azul, op. cit., pp.171-195. En cuanto al árbol como símbolo del centro o imagen arquetípica del mundo, pues participa a la vez de lo visible y lo invisible, estando su energía vital asociada a los poderes femeninos de la creación en la 
Nada hay más reconfortante, a nivel personal, que la experiencia del saber, entendida como un deseo continuo de ir más allá, como expansión de un sentido que no deja de cerrarse, permaneciendo abierto y disponible. Desde este punto de vista, resulta significativa la relación de Ángel Crespo con los escritores de lengua inglesa, tanto poetas como críticos, cuyo diálogo prolongado nos permite ver una escritura en proceso de formación, donde la visión unitaria de lo real, de lo que adviene espontáneamente en el lenguaje, sirve de caracterización a la naturalidad. Por esa razón, en la medida en que el lenguaje da acceso al impulso íntimo de la naturaleza y nos invita al recogimiento, se hace componente esencial de la expresión poética. Releyendo la poesía de Hopkins, cuya síntesis lograda de pensamiento y expresión tanto debe a la meditación de la espiritualidad jesuítica, se percibe su esfuerzo por objetivar la realidad del mundo, pues a ella sólo se accede a través de la intuición. En su ensayo "Hopkins, poeta de la experiencia", publicado por primera vez en 1989, Crespo alude a su cambio de sensibilidad a partir de 1875 , debido a su noviciado en la Compañía de Jesús y su práctica de los ejercicios ignacianos, consistente en una lírica para reconocer el ser y cuya fuerza íntima deriva de una experiencia conjunta de estética y religión:

Fue a partir de entonces, y durante un período de no más de catorce años, cuando escribió la más renovadora poesía inglesa de su época. Una poesía para la que se han buscado muchos calificativos pero a la que creo esencialmente barroca, como influida profundamente por la espiritualidad jesuítica, y que se relaciona tanto con Milton y con Shakespeare como con los poetas llamados metafísicos por la crítica anglosajona. De esta manera, la armonía entre vanguardia y tradición que se advierte en la poesía de Hopkins puede ser comprendida a la luz de los juegos de contrastes propios del estilo barroco.

Refiriéndose al pensamiento de Duns Escoto, al que empezó a leer por primera vez en el verano de 1872, afirma Hopkins: "Precisamente, cuando captaba en mí alguna forma íntima (inscape) del cielo o del mar, pensaba en Escoto", cuya sensibilidad, enriquecida con la experiencia de lo singular, tiende a sobrepasar los objetos, a ver más allá de ellos, en una dialéctica entendida como tensión entre lo particular y lo universal, el orden real del mundo y el misterio de lo inaudito, intensificando para ello la lengua y extendiéndola por encima de su inmanencia. Dado que para Hopkins el hombre es encarnación de lo divino y la precisión del lenguaje poético depende de su poder de encarnación, no resulta extraño que, sirviéndose "de los juegos de contrastes propios del estilo barroco", vuelva a la tradición de la poesía meditativa y, de manera especial, a la de "los poetas llamados metafísicos", tales como Donne, Herbert, Crashaw, Marvell y Vaughan, cuya poesía se caracteriza

mayoría de las tradiciones, tengo en cuenta el trabajo de M.Eliade, Imágenes y símbolos, Madrid, Taurus, 1979, pp.44-50. 
por una "aprehensión sensorial de la realidad", según ha subrayado T.S.Eliot. La unificación de poesía y pensamiento ("Piensa el sentimiento, siente el pensamiento", dice Unamuno en su famoso "Credo poético"), que se da en estos poetas y más tarde en los románticos alemanes (“Tú no vacilas en el límite, sino que en tu espíritu se han compenetrado íntimamente poesía y filosofía", escribe Friedrich Schlegel a propósito de Novalis), constituye una grave carencia de nuestra modernidad. La convergencia o el acuerdo entre filosofía y poesía, entre pensar y sentir, que está siempre presente en las reflexiones de Hopkins sobre su propia actividad creativa, tiene sus raíces en una percepción emotiva del mundo, que es lo que caracteriza al pensamiento poético. Por eso en este fragmento, que vale por todo un tratado de literatura comparada, Crespo subraya la modernidad de Hopkins, haciéndonos ver que el hombre es un sentimiento del mundo, pero un sentimiento que piensa. Ese reconocimiento del mundo en el hombre, que sólo es posible por la poesía, es lo que sitúa a Hopkins entre su tiempo y el nuestro, entre la tradición y la vanguardia. Si el poeta inglés expresó las contradicciones del alma humana, fue porque su cristianismo barroco intentó conciliar los opuestos mediante la flexibilidad musical de la lengua hablada. Con su deseo de decir lo indecible, en cuya expresión paradójica confluyen tanto lo místico como lo barroco, Hopkins supo anticiparse a una de las propuestas de la lírica de nuestra época: en dejar que el mundo se diga a través del poema ${ }^{17}$.

El deseo de integridad, que sólo se alcanza tras una larga experiencia, aparece como un ideal de la creación poética. El propio Juan Ramón Jiménez, aludiendo a su evolución, que le llevó a preocuparse cada vez más por lo esencial y a no separar en su escritura la moral de la estética, nos dice en uno de sus textos inéditos: "Nada tan absurdo como querer desligar las artes. ¿Qué la poesía sea poesía, la música música y la pintura pintura? ¿Y qué es pintura qué música y qué poesía? Una es la naturaleza y nada más ridículo que querer, al interpretarla, olvidarla". Consciente del exceso de realidad que lo sobrepasa, el poeta, como Deucalión, renace de una tierra en ruinas y abre sus ojos a un nuevo mundo en busca de inocencia ("Siempre al mundo viejo / -trabajo y fatiga- / el niño lo salva / con sus ojos nuevos", había dicho Antonio Machado). Y en eso consiste precisamente la poesía, en salvar, con la mirada, lo inmediato para llegar al otro lado del límite, que al ser desconocido

\footnotetext{
$17 \quad$ A la espiritualidad jesuítica de la sensibilidad barroca, puesta ya de relieve por Eugenio D'Ors en su estudio Lo barroco (1936), se ha referido Louis L.Martz en su estudio, The Poetry of Meditation, Yale University Press, 1955. A esta combinación de lo mental y lo afectivo, propia de los poetas metafísicos, se había referido ya T.S.Eliot en su clásico ensayo "The Metaphysical Poets", en Selected Essays, New York, 1932, pp.245-248. Sigo la versión española, Los poetas metafísicos y otros ensayos sobre teatro y religión, Buenos Aires, Emecé Editores, 1944, Tomos I y II. Sobre Hopkins publicó Crespo dos ensayos, ambos con motivo de su centenario: "El eón barroco en la poesía de Gerard Manley Hopkins", en Hora de poesía, 63-64 (1989), y recogido en Por los siglos, pp.155-169; y "Hopkins, poeta de la experiencia", Diario 16 (junio de 1989), y recogido en El poeta y su invención, pp.267-270.
} 
se erige como suprema realidad. En su acceso a lo invisible del mundo, la palabra poética se propone encontrar, más allá de las apariencias, la unidad de lo que está disperso, de ahí que en sus reflexiones sobre lo poético, diseminadas tanto en sus poemas como en sus ensayos, Ángel Crespo, llevado por una paciente maduración, apueste por una visión integral de la realidad, que viene de los orígenes y que hay que mantener a toda costa. Y él mismo lo declara en el texto autobiográfico "Mis caminos convergentes", aludiendo a su formación autodidacta: “No pretendo, al dar cuenta de algo que creo muy común entre los poetas, declarar que yo sea el único artífice de mi forma mentis ni el seleccionador exclusivo de las materias -poéticas o de cualquier otra naturaleza- con que suelo enfrentarme voluntaria o indeliberadadamente, ya para inducir a mi pensamiento y a mi sentimiento, ya para tratar de abrirme camino hacia la integración en una realidad que siempre he intuido, no como ajena a las apariencias, sino como más profunda y reveladora que ellas". Si la experiencia artística vive gracias al contraste entre lo real y lo ideal, esa penetración en lo desconocido, que implica un largo aprendizaje que se añade a lo vivido superándolo, es lo que da sentido a toda creación ("lo que quiere decir que hay que remontarse sobre los datos de la experiencia material para captar en su integridad el verdadero sentido de las cosas", nos dice Crespo en su ensayo "El elefante en la oscuridad", incluido en Las cenizas de la flor). Porque esa visión en profundidad de lo que todavía no se ha alcanzado, pero que se experimenta antes de expresarse, acaso necesite de la música, la más intemporal de las artes, para sentir su lenta formación, pues en ella cabe todo lo posible. Desde su misma irrealidad, donde lo inmediato se libera hasta el límite de lo intrascendente, la música, al vivir en lo imposible, objeto de toda poesía, es la forma más adecuada y precisa para alojar la totalidad del discurso poético, de su virtualidad en expansión, acabando por encontrar un orden en el caos ${ }^{18}$.

Hay, en efecto, a lo largo del proceso creativo un avance lento, una experiencia comparable a la de los místicos, donde la búsqueda nocturna es recompensada al final con el éxtasis de la contemplación reveladora. Sin ese ritual iniciático de la inmersión en lo oscuro, del que hablan los descensos de Ulises, Eneas y Dante, no hay resurrección posible. De ahí que, en ese viaje por las sombras, la palabra alcance su máxima liberación por la música, que así aparece como hilo mediador en su escritura, alcanzando su punto culminante en Iniciación a la sombra (1996), donde

\footnotetext{
18 A pesar del tiempo transcurrido, una buena exposición sobre el diálogo entre las distintas artes puede encontrarse en el estudio de E.Souriau, La correspondencia de las artes. Elementos de estética comparada, México, FCE, 1965. Respecto a la visión de una poética integradora en la escritura crespiana, tengo en cuenta, entre otros, los ensayos de M.T.Bertelloni, "Ángel Crespo. La poesía como discurso total", Anthropos, 97 (1989), pp.52-54; que figura después como "Introducción" a su estudio El mundo poético de Ángel Crespo, Madrid, Huerga y Fierro, 1996, pp.9-15; J.F.Ruiz Casanova, "La realidad entera: Ángel Crespo", Cuadernos Hispanoamericanos, 575 (1998), pp.121-125; y S.Pujol, “Ángel Crespo, hacia una poética integradora", Ínsula, 670 (2002), pp.29-33.
} 
la virtualidad del lenguaje musical tiende a nombrar la realidad en su plenitud. Se progresa en la sombra para acceder a una nueva dimensión. Tal es el movimiento de la música y la poesía hacia lo otro que nos constituye. De esta manera, la forma musical comparte con la poética la fluidez del impulso creador, que abre el lenguaje hacia la transparencia recíproca de la muerte y el origen. Si en los años finales Ángel Crespo se sintió especialmente atraído por la música ("La música, sobre todo, se estaba convirtiendo para él en una necesidad absoluta", afirma Pilar Gómez Bedate en su breve y denso prólogo), es porque, gracias a su delicado fluir, a su poder neutralizador, que tiende a reducir el conflicto entre la presencia y la ausencia ("Abolidas las diferencias, liberada / de sus siete cuevas la luz, / transportaba una música siempre a sí semejante / que, al reflejarse en el callado espejo, / caía como sube el aire, / subía como cae el agua", escuchamos en uno de los poemas de este libro iniciático), la palabra trata de expresar una "visión totalizadora y unitaria de la realidad", recuperando así su dimensión sagrada. La aproximación de la palabra al ideal de la música, ya vigente desde los poetas románticos alemanes, sería para Ángel Crespo una forma de adentrarse en el misterio poético, de contener el mundo en la escritura ${ }^{19}$.

\footnotetext{
19 Aludiendo al sentido integrador de esta escritura en su ensayo "Para situar la obra de Ángel Crespo", afirma P.Gómez Bedate: "La visión integradora entre poesía y vida, utilidad y arte, que había guiado a Crespo desde sus comienzos, le conducía desde siempre a negar a tal oposición como categoría estética y, en su propia poesía, a asimilar no solamente la lección de Juan Ramón Jiménez, sino también la de las vanguardias puras y las impuras en busca de una síntesis que le sirviese en su personal alquimia de la palabra", Ínsula, 670 (octubre 2002), pp.2-4. En cuanto al poder liberador de la música, consustancial a la creación poética, véase el trabajo de J.Neubauer, La emancipación de la música, Madrid, Visor, 1992; y mi ensayo "Iniciación a la sombra: hacia una participación por la música", en Ángel Crespo: una poética iluminante, (ed.), J.M.Balcells, Diputación de Ciudad Real, 1999, pp.357-375.
} 